\title{
TIRPIOS KAVOS IR JOS ANALOGŲ ANTIOKSIDACINIS AKTYVUMAS
}

\author{
Diana Barragan Ferrer, Jesus Manuel Barragan Ferrer, Ieva Kulnickaitė, \\ Vida Čepulkauskienè \\ Kauno kolegijos Medicinos fakultetas
}

Raktažodžiai: kavos analogai, fenoliniai junginiai, antiradikalinis aktyvumas.

\begin{abstract}
Santrauka
Apie tirpių kavų ir jos analogų savybes žinoma kur kas mažiau, nei apie skrudintų kavos pupelių, tačiau žmonių susidomejjimas ir noras rūpintis savo sveikata skatina tirti, kokiomis ypatybėmis pasižymi šie gèrimai ir kokị kiekị rekomenduojama vartoti šių miltelių, kad kava būtų paruošta su aukštesniu antioksidaciniu našumu, kuris naudingai veiktų žmogaus sveikatą. Antioksidaciniu aktyvumu pasižyminčios medžiagos veikia antibakteriškai, skausmą slopinančiai, tonizuojančiai.

Kaip ir ịprastoje kavoje, tirpiojoje ir jos pakaitaluose taip pat randamas didelis kiekis žmogaus organizmui reikalingų antioksidantų, tačiau jų aktyvumas priklauso nuo kavos koncentracijos. Antioksidaciniu aktyvumu pasižyminčios medžiagos gali būti naudojamos lètinių, širdies ir kraujagyslių sistemos ligų, organizmo senejjimo prevencijai ir gydymui, kadangi pasižymi efektyviu oksidacinių procesų blokavimu. Dèl šių priežasčių svarbu nustatyti tirpios kavos ir jos analogų kokybę pagal fenolinių junginių kiekị ir antioksidacinị aktyvumą.

Tyrimo rezultatai parodè, kad bendras fenolinių junginių kiekis, didinant tirpių kavos gèrimų koncentraciją, fenolinių junginių kiekis bekofeininiuose tirpaluose didèjo, o kavose su kofeinu - kito neženkliai. Atlikus antioksidacinių savybių ịvertinimo tyrimą nustatyta, kad didinat kavos koncentraciją antiradikalinis efektyvumas mažeja ir kavos gérimai pradeda veikti oksiduojančiai.
\end{abstract}

\section{Ivadas}

Kaip teigia L.Lankauskaitė, didžiausią kiekị tirpiosios kavos suvartoja penkios pasaulio šalys: Brazilija, Meksika, Kolumbija, Filipinai ir Indija [1]. Bene vienas iš svarbiausių faktų, kurị pabrèžia N.Pučerovas ir R.Cruz, yra tas, kad tirpioji kava gaminama iš tikros kavos žaliavų [2,3]. Maždaug 17 proc. viso pasaulio žalios kavos pupelių produkcijos sunaudojama tirpios kavos gamybai [4]. Labiausiai paplitusios rūšys, naudojamos tirpios kavos gamybai: Coffea arabica (Arabica) ir Coffea canephora (Robusta). C. canephora nepasižymi ryškiomis skonio savybėmis, tačiau leidžia išskirti daug tirpių dalelių, todèl yra ypač vertinama tirpios kavos pramonèje [5]. Arabica kavos pupelès yra brangesnès, nes auginamos derlingesniame dirvožemyje, kur susidaro tam tikros klimato sąlygos, leidžiančios išgauti subtilesnị kavos skonį iš skrudintų pupelių [6]. Kofeinas yra plačiausiai vartojamas stimuliantas pasaulyje, o jo didžiausias mitybos šaltinis yra kava. Stiprus farmakologinis kofeino poveikis sukèlè vartotojų paklausą kurti kavos gėrimus be kofeino [4]. Natūralios kavos pakaitalų paieškos paskatino ieškoti tinkančių kavos rūšių ne tik sveikiems, bet ir sergantiems žmonèms. Negalintiems vartoti kofeino, buvo pradèta gaminti dekofeinizuota kava (tirpios kavos gèrimai), tačiau ji neprilygo skoniu tikrajai rūšinei džiovintų kavos pupelių kavai. N.Pučerovas teigia, kad XVIII a. po daugelio metų paieškų vokiečių sodininkas Timme atrado vieną iš pakaitalų - cikoriją [2]. Cikorijoje yra 75 proc. vandens, šeštadali sudaro insulinas, kuris vykstant hidrolizei virsta fruktoze. İdomu, kad apie 80 proc. sausujjų medžiagų, esančių cikorijoje, tirpsta vandenyje, todèl kepintos cikorijos sudètyje yra daugiau tirpių medžiagų negu natūralioje kepintų pupelių kavoje. Cikorijos užpilas pasižymi tirštumu, stipriu savitu kvapu. Ji neturi tonizuojančių savybių, nes jos sudètyje nėra kofeino [2,7] . Dar vienas tirpios kavos analogas - esencijos. Jos gali būti gaminamos iš miežių, rugių, cukrinių runkelių, avinžirnių, kiaulpienių šaknų, cikorijos lapų, seratonijos ankščiu ir kt. Miežiai mažina gliukozès ir MTL cholesterolio kiekị, kraujospūdị, taip pat yra didelis Zn šaltinis. Skrudintų miežių skonis primena riešutų skonio kavą. Buvo atliktas tyrimas, kuris parode, kad tam tikri rugiuose esantys junginiai užkerta kelią vėžinių ląstelių plitimui. Skaidulos skatina žarnyno peristaltiką, gerina gliukozės toleranciją, yra dide- 
lis probiotikų šaltinis. Dar vienas kultūrinis augalas, įeinantis ị kavos pakaitalu gamybą - cukriniai runkeliai, kuriuose daug $\mathrm{Mg}$, Ca, Fe. Jie pasižymi kraujospūdị mažinančiomis savybèmis. Runkeliai savo sudètyje turi nekenksmingo cukraus, kuris palaiko dienos energijos balansą [8]. Svarbu paminèti, kad šių kultūrų augalai ir grūdai negali būti naudojami kaip pavieniai gaminant kavos gerimus, nes neturi pakankamo kiekio sudedamụjų dalių, reikalingų paruošti didelès energetinès vertès kavos gèrimą. Todèl esencijos ruošiamos derinant kelis skirtingus augalus, pavyzdžiui: rugių, miežių, cikorijų ir cukrinių runkelių.

Tyrimo tikslas - nustatyti tirpios kavos ir jos analogų antioksidacini aktyvumą.

\section{Tyrimo objektas ir metodika}

Tyrimui buvo pasirinkti penki mėginiai: tirpūs cikorijos milteliai (Es-

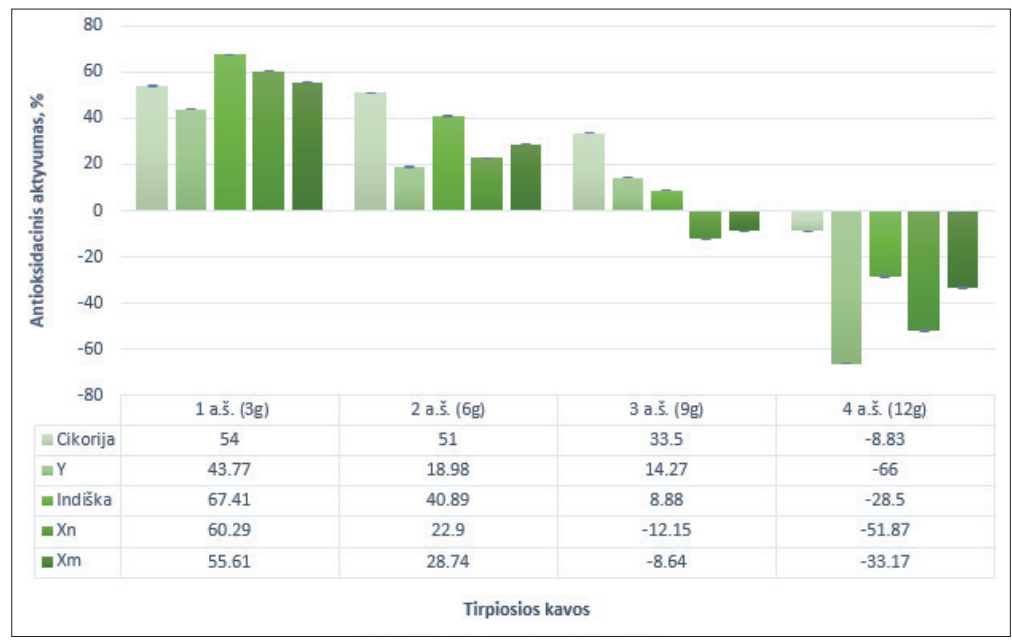

1 pav. Tirpių kavų ir jos analogų antioksidacinis aktyvumas.

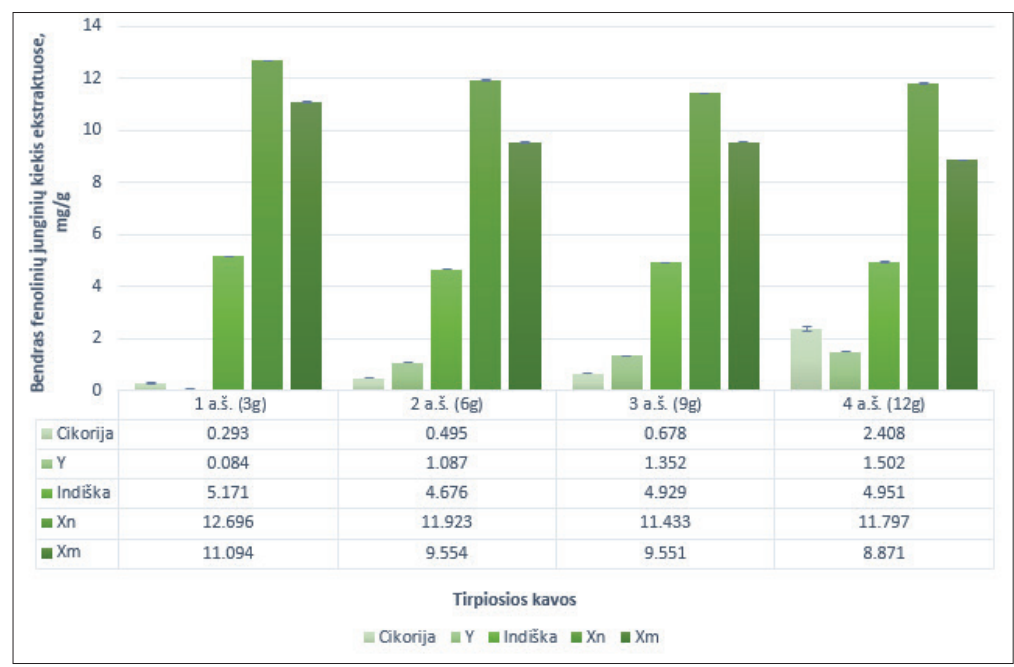

2 pav. Suminis fenolinių junginių kiekis tirpių kavų ir jos analogų ekstraktuose. tija), natūrali miežių, rugių, cikorijų ir cukrinių runkelių esencija $Y$ (Lenkija), indiška kava (Indija), aromatinè $X n$ kava (Vokietija), lazdyno riešutų skonio tirpioji kava $X m$ (Olandija).

Mèginių vandeniniai ekstraktai buvo ruošiami užpylimo metodu.

Užpylimo metodas. Milteliai t.y.: $3 \mathrm{~g}, 6 \mathrm{~g}$, $9 \mathrm{~g}, 12 \mathrm{~g}$ buvo užpilti $200 \mathrm{ml}$ kambario temperatūros distiliuotu vandeniu ir maišomi kol visiškai ištirps.

Suminis fenolinių junginių kiekis. Kavos ir jos analogų vandeninių ekstraktų suminis fenolinių junginių kiekis nustatytas Folin Ciocalteu metodu [9], méginiai veikiami Folin - Ciocalteu ir 7,5\% natrio karbonato tirpalu. Folin - Ciocalteu reagentas skiedžiamas vandeniu santykiu 1:10, $5 \mathrm{ml}$ šio tirpalo sumaišoma

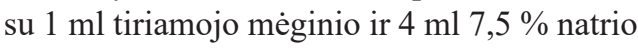
karbonato tirpalu. Paruoštas mėginys valandai talpinamas kambario temperatūroje ị tamsią vietą ir po valandos vykdoma spektrofotometrinè analizè. Mišinio absorbcija matuojama esant $765 \mathrm{~nm}$ bangos ilgiui. Suminis fenolinių junginių kiekis išreiškiamas galo rūgšties ekvivalentais (GAE) vienam gramui žaliavos. Kalibracinei kreivei naudojame galo rūgšties vandeninį tirpalą $(0,0125-0,4 \mathrm{mg} / \mathrm{ml}))$. Fenolinių junginių kiekis apskaičiuojamas pagal formulę: $\mathrm{GAE}=\mathrm{c} \times \mathrm{V} / \mathrm{m}, \mathrm{mg} / \mathrm{g}$, kur c - galo rūgšties koncentracija $\mathrm{mg} / \mathrm{ml}$ nustatyta iš kalibracinès kreivès; $\mathrm{V}$ - ekstrakto tūris $\mathrm{ml} ; \mathrm{m}$ - tikslus atsvertas žaliavos kiekis g.

Antiradikalinis aktyvumas. Kavos ir jos analogų vandeninių ekstraktų antioksidacinis aktyvumas nustatytas 2,2-difenil-1-pikrilhidrazilo $\left(\mathrm{DPPH}^{\circ}\right)$ radikalo sujungimo metodu [10]. Antiradikalinis aktyvumas įvertinamas matuojant, kiek procentų stabilaus 2,2-difenil-1-pikrilhidrazilo $\left(\mathrm{DPPH}^{\circ}\right)$ radikalo neutralizuoja prieskonių sudetyje esantys ir antioksidaciniu aktyvumu pasižymintys junginiai. $50 \mu \mathrm{l}$ vandeniniai ekstraktai sumaišomi $1 \mathrm{~cm}$ kiuvetèje su $2 \mathrm{ml} 6 \times 10^{-5} \mathrm{M}$ etanolinio $\mathrm{DPPH}^{*}$ tirpalo. Spektrofotometru matuojamas mėginių absorbcijos sumažèjimas, kai bangos ilgis buvo $515 \mathrm{~nm}$ ir kol pasiekiama pusiausvyra (apie 30 min.). Antioksidacinis aktyvumas apskaičiuojamas inaktyvuoto DPPH' kiekio procentais: $\mathrm{DPPH}_{\text {inaktyv. proc }}=\left[\left(\mathrm{A}_{\mathrm{b}}-\mathrm{A}_{\mathrm{a}}\right) / \mathrm{A}_{\mathrm{b}}\right] \times 100$, kur: $\mathrm{A}_{\mathrm{b}}-$ tuščiojo bandinio absorbcija ( $\mathrm{t}=0 \mathrm{~min}$.), $\mathrm{A}_{\mathrm{a}}-$ 
bandinio su tiriamuoju tirpalu absorbcija ( $\mathrm{t}=30 \mathrm{~min}$.). Kavos ir jos analogų ekstraktuose esančių antiradikališkai aktyvių junginių aktyvumas vertinamas pagal standartini (etaloninị) antioksidantą troloksą. Ekstraktuose nesurištų radikalų kiekis išreiškiamas mM/L, ekvivalentiškais troloksui.

\section{Tyrimo rezultatai}

Kavos ir jos analogų vandeninių ekstraktų antiradikalinių savybių ịvertinimas laisvųjų radikalų modelinejje sistemoje. Tirpių cikorijos miltelių, natūralių miežių, rugių, cikorijų ir

1 lentelè. Antioksidacinè galia ir fenolinių junginių kiekis ekstraktuose.

\begin{tabular}{|c|c|c|c|}
\hline Kiekis (g) & Kava & $\begin{array}{l}\text { F e n o l i n i uc } \\
\text { junginių kie- } \\
\text { kis ekstrakte, } \\
\text { mg/g }\end{array}$ & TEAC, $\mathrm{mM} / \mathrm{L}$ \\
\hline 1 a. š. $(3 g)$ & \multirow{4}{*}{ Cikorija } & $0,29 \pm 0,005$ & $1,09 \pm 0,049$ \\
\hline 2 a. š. $(6 g)$ & & $0,50 \pm 0,005$ & $1,03 \pm 0,091$ \\
\hline 3 a. š. $(9 \mathrm{~g})$ & & $0,68 \pm 0,001$ & $0,67 \pm 0,093$ \\
\hline 4 a. š. (12 g) & & $2,41 \pm 0,093$ & $-0,19 \pm 0,194$ \\
\hline 1 a. š. $(3 \mathrm{~g})$ & \multirow{4}{*}{$\mathrm{Y}$} & $0,08 \pm 0,003$ & $0,88 \pm 0,050$ \\
\hline 2 a. š. $(6 g)$ & & $1,09 \pm 0,004$ & $0,38 \pm 0,028$ \\
\hline 3 a. š. $(9 \mathrm{~g})$ & & $1,35 \pm 0,005$ & $0,28 \pm 0,108$ \\
\hline 4 a. š. (12 g) & & $1,50 \pm 0,004$ & $-0,19 \pm 0,162$ \\
\hline 1 a. š. $(3 \mathrm{~g})$ & \multirow{4}{*}{ Indiška } & $5,17 \pm 0,006$ & $1,36 \pm 0,038$ \\
\hline 2 a. š. $(6 g)$ & & $4,68 \pm 0,004$ & $0,82 \pm 0,057$ \\
\hline 3 a. š. $(9 \mathrm{~g})$ & & $4,93 \pm 0,004$ & $0,17 \pm 0,057$ \\
\hline 4 a. š. (12 g) & & $4,95 \pm 0,014$ & $-1,35 \pm 0,134$ \\
\hline 1 a. š. $(3 g)$ & \multirow{4}{*}{$\mathrm{Xn}$} & $12,70 \pm 0,001$ & $1,22 \pm 0,030$ \\
\hline 2 a. š. $(6 g)$ & & $11,92 \pm 0,009$ & $0,46 \pm 0,094$ \\
\hline 3 a. š. $(9 \mathrm{~g})$ & & $11,43 \pm 0,002$ & $-0,25 \pm 0,066$ \\
\hline 4 a. š. (12 g) & & $11,80 \pm 0,010$ & $-1,06 \pm 0,081$ \\
\hline 1 a. šs. $(3 \mathrm{~g})$ & \multirow{4}{*}{$\mathrm{Xm}$} & $11,09 \pm 0,012$ & $1,22 \pm 0,020$ \\
\hline 2 a. š. $(6 g)$ & & $9,55 \pm 0,027$ & $0,58 \pm 0,010$ \\
\hline 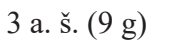 & & $9,55 \pm 0,003$ & $-0,18 \pm 0,049$ \\
\hline 4 a. ̌s. (12 g) & & $8,87 \pm 0,011$ & $-0,68 \pm 0,103$ \\
\hline
\end{tabular}

cukrinių runkelių esencijos $Y$, indiškos tirpiosios kavos; Xn ir $\mathrm{Xm}$ aromatinių kavų ekstraktų antioksidacinès savybės buvo vertinamos DPPH' radikalo sujungimo metodu. Šių kavų ekstraktu antioksidacines savybes lemia juose esantys fenoliniai junginiai, kurie veikia kaip antioksidantai. D.G.Bassoli ir kt. tvirtina, kad kavos antioksidacinis pajègumas priklauso nuo natūralių ingredientų ir junginių, kurie susidaro kavos apdorojimo proceso metu [5]. Kavų ekstraktų vertinimas pagal 2,2-difenil-1-pikrilhidrazilo (DPPH') radikalo sujungimą informatyvus, bet ypač jautrus aplinkos veiksniams rodiklis, todèl būtina atsižvelgti ị visus faktorius, kurie gali paveikti rezultatus. Atlikto tyrimo rezultatai parodo, kaip keičiasi skirtingų tirpių kavų rūšių ir jos pakaitalų antiradikalinis efektyvumas priklausomai nuo koncentracijos (1 pav.)

Remiantis 1 pav. pateiktais duomenimis, galima teigti, kad mažiausios koncentracijos (3 g/1 arbatinis šaukštelis) tirpios kavos vandeniniai ekstraktai pasižymi didžiausiu antiradikaliniu efektyvumu (67 - 44 proc.), o didinant koncentraciją, efektyvumas dèsningai mažèja. Didžiausiu antioksidaciniu aktyvumu pasižymi tirpūs cikorijos milteliai (54 - 34 proc.), kurių koncentraciją padidinus iki 12 g., absorbcija ženkliai išauga ir pradeda vykti atvirkštinis procesas - oksidacija. 2 a. š. (6 g) ir 3 a. š. (9 g) tirpiosios esencijos Y antioksidacinès savybės žymiai mažèja iki 19-14 proc. Indiškos kavos vandeninio ekstrakto antiradikalinis efektyvumas ženkliai sumažèja paruošus 3 a. š. $(9 \mathrm{~g})$ koncentracijos gérimą. Xn ir Xm oksiduojančiai pradeda veikti su 3 a. š. $(9$ g) tirpalais. Stebint šį dèsningumą svarbu paminèti, kad padidinus koncentraciją iki 4 a. š. (12 g) absoliučiai visi gėrimai pradeda veikti oksiduojančiai, iš kurių stipriausiai veikia $Y$ (-66 proc.) ir Xn (-52 proc.). Galima teigti, kad antioksidacinis aktyvumas atvirkščiai proporcingas koncentracijai, t. y. kuo didesnè koncentracija, tuo ekstraktas pasižymi silpnesniu antioksidaciniu efektyvumu, todèl optimaliausias pasirinkimas yra vartoti 1-2 a. š./(3-6 g) koncentracijos tirpiają kavą.

Fenolinių junginių kiekis tirpioje kavoje ir jos analoguose. D.Dobravalskyte ir kt. teigia, kad ekstraktų, pagamintų iš augalinès kilmés produktų, radikalų sujungimo geba dažniausiai priklauso nuo juose randamų fenolinių junginių koncentracijos [11]. Vertinant tirpiosios kavos gèrimų kokybę svarbu nustatyti kavos vandeniniuose ekstraktuose esančių fenolinių junginių kiekį. Atlikus tyrimą nustatyta (2 pav.), kad didžiausias fenolinių junginių kiekis yra $X n(12.70 \mathrm{mg} / \mathrm{g})$ ir $X m(11.09 \mathrm{mg} / \mathrm{g})$ visų keturių koncentracijų tirpiosiose kavose. Didejjant šių aromatinių kavų (įskaitant indišką) fenolinių junginių kiekio priklausomybė nuo koncentracijos kinta neženkliai. Galima pastebėti, kad didinant tirpios cikorijos, miežių esencijos $Y$ kavos koncentracijas absorbcija didejja, t. y. šiuose tirpių kavų pakaitaluose randamas didesnis fenolinių junginių kiekis. Apibendrinus tyrimo rezultatus 
galima teigti, kad didinant koncentraciją, fenolinių junginių kiekis dideja tik tuose kavos gèrimuose, kuriuose nėra kofeino. Rezultatai parodè, kad tiesioginès priklausomybès tarp fenolinių junginių kiekio ir radikalų sujungimo gebos nëra.

Remiantis 1 lenteleje pateiktais duomenimis, galima teigti, kad didinant tirpios kavos gérimų koncentraciją fenolinių junginių kiekis bekofeininiuose tirpaluose didejja, o kavose su kofeinu - kinta neženkliai, bet antiradikalinis efektyvumas mažèja. Remiantis tyrèjų D.G.Bassoli ir kt. bei D.Komes ir kt. atliktais tyrimais, galima teigti, kad ekstrahavimas aukštoje temperatūroje gali turèti ịtakos antioksidantų kiekiui kavoje, todèl galime daryti prielaidą, kad tirpios kavos gamybos proceso metu keičiasi kavos sudètinès dalys, dèl kurių pakinta kavos antioksidacinès savybès ir didesnès koncentracijos kava pasižymi oksiduojančiu poveikiu $[4,5]$.

\section{Išvados}

1. Antioksidacinès savybès nustatomos DPPH· radikalo sujungimo metodu. Didžiausiu antiradikaliniu efektyvumu pasižymi visos tirpiosios kavos ir bekofeininiai gèrimai, kurių koncentracija buvo paruošta su 1 a. š./ 3 g. Padidinus kavos koncentraciją iki 4 a. š./ 9 g., kavos gérimai ir jų pakaitalai veikè oksiduojančiai.

2. Fenoliniu junginių kiekio nustatymas spektrofotometriniu Folin - Ciocalteu metodu parode, kad didinant koncentraciją, fenolinių junginių kiekis didèja tik tuose kavos gérimuose, kuriuose nėra kofeino. Nustatyta, kad fenoliniu junginių kiekis nèra tiesiogiai proporcingas antioksidaciniam aktyvumui. Galima teigti, kad tirpios kavos ir jos analogu radikalų sujungimo geba nepriklauso nuo fenolinių junginiu kiekio.

\section{Literatūra}

1. Lankauskaitè L., Kelle M., Kang A. Kavos gurmanai. Ekspress leidyba. Vilnius, 2010.

2. Pučerovas N. Viskas apie kavą. Mokslas. Vilnius, 1991.

3. Cruz R, Morais S, Casal S. Mineral composition variability of coffees: a result of processing and production. Processing and Impact on Active Components in Food, 2015; 66: 549-558. https://doi.org/10.1016/B978-0-12-404699-3.00066-4

4. Komes D, Belščak-Cvitanovic A. Effects of preparation techniques on the antioxidant capacity of coffee brews. Processing and Impact on Antioxidants in Beverages, 2014; 10: 87-97. https://doi.org/10.1016/B978-0-12-404738-9.00010-6

5. Bassoli DG, Vignoli JA, Benassi MT. Antioxidant activity, polyphenols, caffeine and melanoidins in soluble coffee: the influence of processing conditions and raw material. Food Chemistry, 2011;124:863-868.

https://doi.org/10.1016/j.foodchem.2010.07.008

6. Huang M, Zhang M. Tea and coffee powders. Handbook of
Food Powders, 2013;20: 513-531.

https://doi.org/10.1533/9780857098672.3.513

7. Petkevičiūtè L. Apie arbatą ir kavą. Gamta. Vilnius, 2002.

8. Dorea J, da Costa T.. Is coffee a functional food? British Journal of Nutrition 2005; 93(6):773-782.

https://doi.org/10.1079/BJN20051370

9. Folin O, Ciocalteu V. On tyrosine and tryptophane determinations in proteins. The Journal of Biological Chemistry 1927;73(2):627-650.

10. Brand-Williams W, Cuvelier ME, Berset C. Use of a free radical method to evaluate antioxidant activity. LWT-Food Science and Technology 1995;28(1):25-30.

https://doi.org/10.1016/S0023-6438(95)80008-5

11. Dobravalskytė D, Venskutonis PR, Talou T. Antioxidant properties and essential oil composition of Calamintha grandiflora L. Food Chemistry, 2012;135(3):1539-1546.

https://doi.org/10.1016/j.foodchem.2012.05.094

\section{ANTIOXIDANT ACTIVITY OF SOLUBLE COFFEE} AND THEIR SUBSTITUTES

\section{D.Barragan Ferrer, J.M.Barragan Ferrer,} I.Kulnickaitė, V.Čepulkauskienė

Key words: coffee analogs, phenolic compounds, antiradical activity.

Summary

The properties of instant coffee and their analogs are much less known than roasted coffee beans, but the great interest of people for knowing their health properties promotes the investigation of this type of beverage. Beneficial effects such as anti-bacterial, pain-suppressant, tonic effects that are associated with the higher antioxidant capacity of this type of beverage. To determine this antioxidant capacity of soluble coffee and its analogs/substitutes it is necessary to determine the amount of phenolic compounds and the antioxidant activity. Thus, in this research, we evaluate the total soluble phenolic compounds content and the antioxidant capacity of aqueous extracts of instant coffee and its analogs using the Folin - Ciocalteu spectrophotometric method and the antiradical efficiency by DPPH radical interconnection method.

The total determination of the phenolic compounds showed that increasing concentrations of soluble coffee increased the content of phenolic compounds in decaffeinated solutions, while in the case of caffeinated coffee it was not significant. An antioxidant evaluation study showed that increasing the concentration of antiradical effects decreases and the coffee beverages start to act as an oxidizing agent.

Correspondence to: diana.barragan.ferrer@go.kauko.lt

Gauta 2018-09-13 